\title{
Malaysian and Thais Consumers' Perception and Attitude towards Electronic Payment
}

Mohd Halim Mahphoth, Ahmad Tarmizi Abu Zaki, Shafinar Ismail, Kasidit Chaiphawang, Siripan Jeenaboonrueang, Andhi Wijayanto

To Link this Article: http://dx.doi.org/10.6007/IJARBSS/v10-i12/8025

DOI:10.6007/IJARBSS/v10-i12/8025

Received: 09 October 2020, Revised: 06 November 2020, Accepted: 24 November 2020

Published Online: 18 December 2020

In-Text Citation: (Mahphoth et al., 2020)

To Cite this Article: Mahphoth, M. H., Zaki, A. T. A., Ismail, S., Chaiphawang, K., Jeenaboonrueang, S., \& Wijayanto, A. (2020). Malaysian and Thais Consumers' Perception and Attitude towards Electronic Payment. International Journal of Academic Research in Business and Social Sciences, 10(12), 631-637.

Copyright: (c) 2020 The Author(s)

Published by Human Resource Management Academic Research Society (www.hrmars.com)

This article is published under the Creative Commons Attribution (CC BY 4.0) license. Anyone may reproduce, distribute, translate and create derivative works of this article (for both commercial and non-commercial purposes), subject to full attribution to the original publication and authors. The full terms of this license may be seen at: http://creativecommons.org/licences/by/4.0/legalcode

Vol. 10, No. 12, 2020, Pg. 631 - 637

Full Terms \& Conditions of access and use can be found at http://hrmars.com/index.php/pages/detail/publication-ethics 


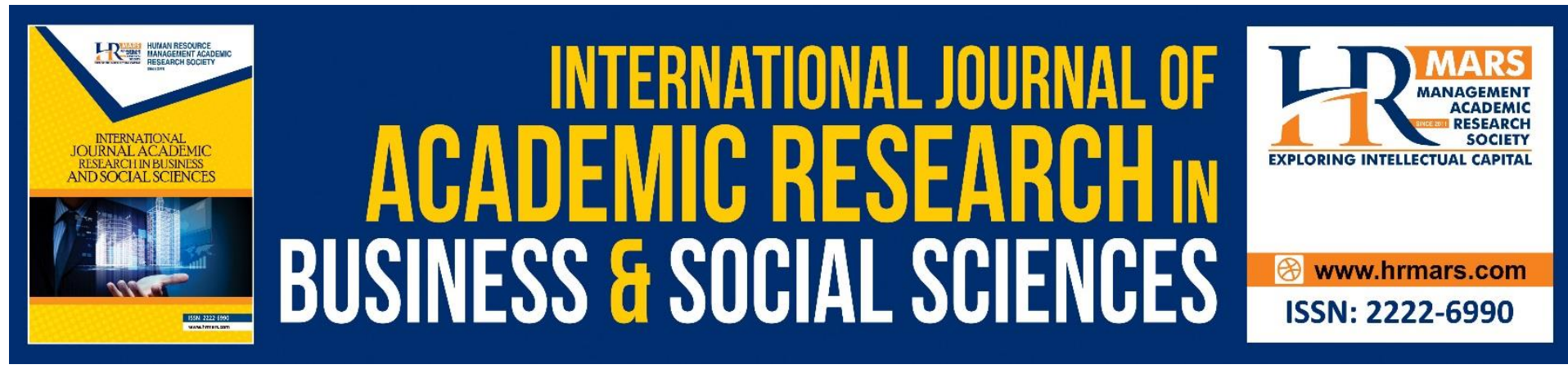

\title{
Malaysian and Thais Consumers' Perception and Attitude towards Electronic Payment
}

\author{
Mohd Halim Mahphoth ${ }^{1}$, Ahmad Tarmizi Abu Zaki², Shafinar \\ Ismail $^{3}$, Kasidit Chaiphawang ${ }^{4}$, Siripan Jeenaboonrueang ${ }^{5}$, \\ Andhi Wijayanto 6 \\ 1,2,3 Faculty of Business and Management, Universiti Teknologi MARA Cawangan Melaka, \\ 110 Off Jalan Hang Tuah, 75300 Melaka, Malaysia, 4,5Faculty of Management Science, \\ Chiang Rai Rajabhat University, 80 Village No. 9, Ban Du Subdistrict, Mueang District, Chiang \\ Rai Province 57100, Thailand, ${ }^{6}$ Faculty of Economics, Universitas Negeri Semarang, Gedung \\ L1 Kampus Sekaran, Gunungpati, Semarang 50229 Indonesia
}

\begin{abstract}
Today, electronic payment (e-payment) has become a major point of consideration for consumers, businesses and the public sector. E-payment customers make cashless payments for goods and services through cards, mobile phones or the internet. Perception of consumers towards these e-payment systems is highly important for future growth. This paper deals mainly with the theories and concepts of consumer perception towards e-payment system. With the central focus of providing insights in the context of Malaysians and Thais consumers' perception and attitude towards electronic payment, this study determined factors namely security, trust, benefits, self-efficacy, and ease of use deduced from Theory of Technology Acceptance Model (TAM). Appropriate strategies to support the operators in promoting the use of e-payments were also being discussed.
\end{abstract}

Keywords: Attitude, Consumers' Perception, E-Payment, Technology Acceptance Model (TAM)

\section{Introduction}

Electronic payment or well-known as e-payment refers to conducting payment transaction over an electronic device. Nowadays, this method of payment is driven by the phenomenon of e-commerce. Sumanjeet (2009) has highlighted this payment instrument has gained their popularity as it has been facilitated by the internet growth as many cases cannot be effectively fulfilled by traditional payment systems, so electronic commerce (e-commerce) has created new financial needs for it. Since then, many e-payment systems and their providers have arise and slowly expand along with the advancement of an e-commerce transactions.

In Malaysia, this e-payment systems can be differentiated into three categories. The first category is retail payment systems. There are several types in retail payment systems such as national cheque information clearing system, shared Automated Teller Machine (ATM) network, e-debit, Interbank GIRO, financial process exchange, and direct debit. The second category is retail payment instruments namely credit card, charge card, debit card, e-money. 
The last category is retail payment channels such as an Automated Teller Machine (ATM), internet banking, mobile banking, and other e-payment. Even though Ramalingam (2012) figure out that Malaysia is stimulating towards receiving greater, attractive, online majority online e-payments, but people in Malaysia are still considered "infants" with a flimsy of internet level knowledge, and this raises concerns to the usage of e-payments (Luarn and Lin, 2005; Paynter and Lim, 2001). This problem causes users to refuse to engage in e-commerce activities, and this will affect merchants who are losing potential customers.

In Thailand, electronic payment has become popular to Thais and SMEs businesses. The reason is the growth of e-commerce in Thailand, the adaptation of both government and private organization to the business environment that offer variety of payment channels to their customers and e-payment is proved to be the fast and effective way of doing the transaction. In the last three years, electronic funds transfer in Thailand has increased to $116 \%$ (Siriratchaneekorn, 2019) per year as a result of Thailand National e-payment strategy. The strategy has started at the end of 2015 with the aims to develop an effective e-payment system.

Though the increasing rate of e-payment in Thailand, but still the large number of people use cash for their transaction. Cash is considered to be a practical option for Thai people who would go buying from street foods, mom and pop shops and pay for transportation such as taxis or motorbike taxis (Appsynth, 2018).

In the past few years, the government, financial institutions and business sectors has tried to expand the e-payment usage in Thailand. Siriratchaneekorn (2019) mentioned that merchants has more methods of receiving payment other than cash and customers are able to pay with cards or mobile banking which makes the transaction easy and convenient. Now, there are about 700,000 EDC terminals and 3 million QR code points of payment in Thailand. This enhances a rapidly growth of e-payment in Thailand.

\section{PAYMENT IN THAILAND (2016)}

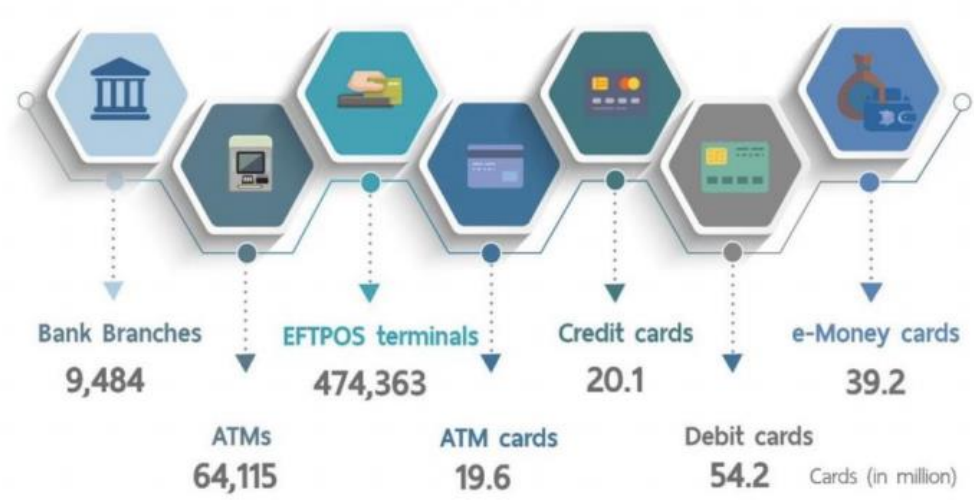

Figure 1: Payment in Thailand as of 2016 (Bank of Thailand, 2016)

From figure 1, it showed the payment channels in Thailand which transactions were conducted through bank branches, ATMs, EFTPOS (Electronic Funds Transfer at Point of Sale), ATM cards, credit cards, debit cards and e-Money cards. 


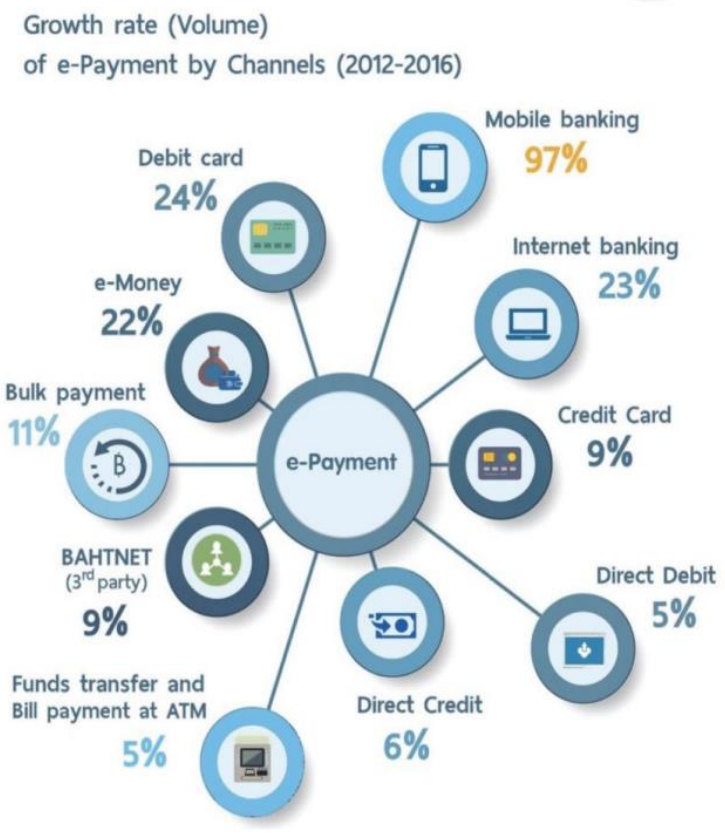

Figure 2: Growth rate of e-Payment by channels as of $2012-2016$

(Bank of Thailand, 2016)

Figure 2 demonstrated the growth rate of e-payment by channels from 2012 to 2016 . It showed that mobile banking was the e-payment channel that has the highest growth rate in Thailand with debit card and internet banking consecutively.

Hence, these paper highlighted five important factors influencing the perception of epayment which are security, trust, benefits, self-efficacy, and ease of use. (Haque et al., 2009; Özkan et al., 2010) stated that there is little study to date in these factors under consideration and related studies are only conducted outside Malaysia. Therefore, it is interesting to study these factors especially on the predictions that e-payment used will grow at a favorable rate over the next few years. These findings will allow important factors to be identified so that appropriate strategies can be formulated to support the operators in promoting the use of epayments among Malaysians and Thais.

\section{Theory of Technology Acceptance Model (TAM)}

This study focuses on the consumer-based study orientation such as consumers' perception towards electronic payment. One of the most widely used models is the Technology Acceptance Model (TAM), a model developed to examine the technology acceptance by individuals who take into account the basics, both the ease of use and the use of technology. TAM was initially recommended by Davis (1989). It consists of two beliefs, perceived utilities, and application-based considerations, which determine the attitude of adopting new technologies. The attitudes towards use will determine the positive or negative behavior of future technologist receivers. TAM suggests that when new technologies being introduced to users, several factors will decide their decision on how and when they will use it. Technology acceptance models evolved over time and various versions available (Priyanka and Kumar, 2013). Furthermore, the Technology Acceptance Model (TAM) is attain from the Theory of Reason (TRA) (Fishbein and Ajzen, 1975), in which TRA describes the theory of behaviour while the TAM is more specialized "information systems". 


\section{Consumers' Perception towards Electronic Payment}

The traditional e-payment system has many limitations that prevent users from using them. Previous studies show that some factors are related to lack of trust, safety, usability, high transaction costs, lack of perceived advantages and perceived risks. Hence, customers feel confidence to migrate to online payment systems due to this important factors. Moreover, research by Abrazhevich (2004) stated that customers will cease engaging in online activities if these prerequisites are not facilitated in the payment system, thereby causing traders to lose potential online sales. Wali (2014) outlined that the electronic payment system is a system that makes payment exchanges applicable via electronic mechanisms.

Then, a payment or financial transactions made through the internet or computer network described as an electronic payment system (Kulkarni, 2004). The feasibility of technology concerning security, trust, and efficiency will also affect the user's decision to use e-payments. Based on this premise, attitude towards e-payments has been carried out in this study regarding the perception that it is better than traditional payment channels, that it is reliable and safe, easy to use, and efficient. In addition, an e-payment consumer refers to a user using an e-payment channel and a tool to complete payment behaviour.

This is because e-payment users have the opportunity to send or direct payment orders via electronic terminals either by itself or by authorizing others, to realize the payment of money and transfer of capital. E-payments provide online payments, telephone payments, mobile payments, and self-service terminals. One of the most widely used models is the Technology Acceptance Model (TAM), a model developed to examine the technology acceptance by individuals who take into account the basics, both the ease of use and the use of technology. TAM was initially recommended by (Davis, 1989). It consists of two beliefs, perceived utilities, and application-based considerations, which determine the attitude of adopting new technologies.

\section{Attitudes towards Electronic Payment}

The attitudes towards use will determine the positive or negative behavior of future technologist receivers. TAM suggests that when new technologies being introduced to users, several factors will decide their decision on how and when they will use it. Technology acceptance models evolved over time and various versions available (Priyanka and Kumar, 2013). TAM explains how people adopt and use the information system in our case it is a digital wallet system.

Alharbi and Drew (2014) studies confirm the relationship between perceived ease of use, perceived use, attitudes towards use, and overall impact on behavioural intentions to be used. No surprising findings were found on previous constructs. Lai (2016) stated that the rate at which the payment system is growing depends on the struggle between rapid technological change and natural barriers to new products or service acceptance.

Later, consumer behaviour is also influenced by internal and external factors (Pornsakulvanich and Dumrongsiri, 2013), and this is true also about consumer usage of electronic payment services. After a period of use of this service, consumers are getting extensive internal information that can help them evaluate their intentions to continue using electronic payments. In the midst of fierce competition today, competing firms' marketing efforts may be an external factor in their decisions.

Since many electronic payment applications support individual payments to individuals, the attitude of others may be other external factors. In short, it is arguable that consumer intentions to continue the use of electronic payment services are influenced by the 
experience of using (internal factors) and market competition and other people's opinions (external factors).

Furthermore, the government and central bank of Malaysia, Bank Negara Malaysia (BNM) are keen to encourage the use of electronic payments, debit cards in particular, as it helps consumers to manage their cash flows carefully and act as tools for ordering credit card debt. Internet banking is also promoted as an alternative way of transferring money, replacing cheques.

Although various guidelines and incentives for promoting electronic payments have been outlined by the Malaysian government, Malaysia's cash usage is still high - about 90 percents of transactions are conducted using this payment method (Tee, 2015). Hence, a lot of effort is needed to reduce dependence on cash and promote non-cash transactions.

Finally, despite the central bank's efforts, the existing mindset of the costs and concerns poses a challenge to the use of electronic payments. Australian APEC Study Centre and TRPC (2015) highlighted that other components of the index such as demand, innovative product and services, and infrastructure are lagging behind the country's policy environment.

\section{Conclusion}

In conclusion, a good perception of consumers towards e-payment is important to influence the usage of e-payment. The consumers need to be taken care by the e-payment service providers to increase their reputation and services offered in e-payment systems. This study note is of the view that while Malaysian policies provide a strong regulatory environment that encourages businesses and consumers to move towards cashless transactions, these measures are inadequate and there are demand factors that prevent the adoption of cashless technology. In Thailand, cash is a major option being used for a small amount of payment because most Thais get use to have cash with them, but they prefer e-payment for a big amount of financial transaction because they feel safe and able to track the transaction history. Generation is another factor that effect the perception of consumers towards epayment. In Thailand it was found that generation $Y$ is the highest portion of e-payment users because they are familiar with technology and they have better understanding about the epayment systems (ThaiFinTech, 2018; Darwish et al., 2020).

\section{References}

Abrazhevich, D. (2001). Classification and characteristics of electronic payment systems. In International Conference on Electronic Commerce and Web Technologies (pp. 81-90). Springer, Berlin, Heidelberg.

Alharbi, S., \& Drew, S. (2014). Using the technology acceptance model in understanding academics' behavioural intention to use learning management systems. International Journal of Advanced Computer Science and Applications, 5(1), 143-155.

Davis, F. D. (1989). Perceived usefulness, perceived ease of use, and user acceptance of information technology. MIS quarterly, 319-340.

Darwish, S., Alzayed, S., \& Ahmed, U. (2020). How Women in Science can Boost Women's Entrepreneurship: Review and Highlights. International Journal of Innovation Creativity and Change, 14(1), 453-470.

Fishbein, M. A., \& Ajzen, I. (2011). I.(1975). Belief, attitude, intention and behaviour: An introduction to theory and research. Reading, Addison-Wesley.

Four Things to Know about e-Payment in Thailand. (2018). ThaiFinTech. Retrieved 
30 October 2019, from http://www.thaifintech.com/2018/03/02/thailandnationalepayment/

Haque, A., Tarofder, A. K, Rahman, S., and Raquib, M. A. (2009), "Electronic transaction of internet banking and its perception of Malaysian online customers", African Journal of Business Management, Vol. 3 No. 6, pp. 248-259.

Kulkarni, A. (2004). Legal Analysis of Electronic Payment Systems: Asian School of Cyber Laws. Kumar, M. A., \& Priyanka, S. (2014). A study on adoption of E-recruitment using Technology Acceptance Model (TAM) with reference to graduating students in universities in Bahrain. International Journal of Advance Research in Computer Science and Management Studies, 2(9), 377-383.

Lai, P. C. (2016). Design and Security impact on consumers' intention to use single platform Epayment. Interdisciplinary Information Sciences, 22(1), 111-122.

Luarn, P., \& Lin, H. H. (2005). Toward an understanding of the behavioral intention to use mobile banking. Computers in human behavior, 21(6), 873-891.

Özkan, S., Bindusara, G., and Hackney, R. (2010), "Facilitating the adoption of e-payment systems: theoretical constructs and empirical analysis", Journal of Enterprise Information Management, Vol. 23 No. 3, pp. 305-325.

Payment Systems Report. (2016). Bank of Thailand. Retrieved 30 October 2019, from https://www.bot.or.th/English/PaymentSystems/Publication/PS_Annually_Report/Do cu ments/Payment_2016_E.pdf

Paynter, J., \& Lim, J. (2001). Drivers and impediments to e-commerce in Malaysia. Malaysian Journal of Library \& Information Science, 6(2), 1-19.

Pikkarainen, T., Pikkarainen, K., Karjaluoto, H., \& Pahnila, S. (2004). Consumer acceptance of online banking: an extension of the technology acceptance model. Internet research, 14(3), 224-235.

Priyanka, S., \& Kumar, A. (2013). Understanding the evolution of technology acceptance model. International Journal of Advance Research in Computer Science and Management Studies, 1(6), 144-148.

Ramalingam, K. (2012). Is Malaysia ready for greater adoption of e-payments? Retrieved March 22, 2020, from https://www.theedgemarkets.com/article/malaysia-readygreater-adoption-e-payments-1

Rubin, A., \& Babbie, E. R. (2009). Essential research methods for social work: Brooks. Cole Pub Co.

Siriratchaneekorn A. (2019). National e-Payment: Turning Thailand into Digital Payment. Bank of Thailand. Retrieved 29 October 2019, from

https://www.bot.or.th/Thai/ResearchAndPublications/articles/Pages/Article24Jan2019.aspx

Sumanjeet, S. (2009). Emergence of payment systems in the age of electronic commerce: The state of art. Global Journal of International Business Research, 2(2).

Tee, L. S. (2015). Going cashless as a way of life. Retrieved March 22, 2020, from https://www.thestar.com.my/business/business-news/2015/01/10/going-cashless-asa-way-of-life-efforts-are-under-way-to-promote-the-widespread-use-of-debit-cards/

The Rise of Thailand's Cashless Economy. (2018, May). Appsynth. Retrieved 29 October 2019, from https://appsynth.net/blog/thailand-cashless-economy/

Wali, A. F., Wright, L. T., \& Reynolds, P. L. (2014). Cashless system, users' perception and retail marketing performance. International journal of sales retailing and marketing, 3(4), 1732. 